\title{
Pengembangan formula enteral hepatogomax untuk penyakit hati berbasis tepung kedelai dan tepung susu kambing
}

\author{
Tia Sofa Rahmadanti, Aryu Candra, Choirun Nissa*
}

\section{ABSTRACT}

Background: Patients with chronic liver disease were risk to be malnourished due to malabsorption, hipermetabolic condition, and not receiving adequate nutrients orally. Diet therapy through enteral feeding based on soybean flour and goat milk flour play role as an alternative formula for chronic liver patients since it contains high Branched-Chain Amino Acids (BCAA) and Medium-chain Triglyceride (MCT).

Objectives: to analyze viscosity, nutrient content, protein digestibility, and organoleptic properties of enteral feeding using soybean flour and goat milk flour.

Methods: An experimental study using 3 distinc formula with ratio soybean flour to goat milk flour was P1(45:55), P2(50:50), P3(55: 45). Viscosity, fat, carbohydrate content, and energy density were analyzed using One Way Anova followed by Tukey test while protein content, protein digestibility, and energy density were analyzed using Kruskal Wallis followed by Mann Whitney test. Organoleptic properties were analyzed using Friedman followed by Wilcoxon test.

Results:The higher the soybean flour, the higher the formula viscosity $(p=0.000)$ and protein $(0.007)$. In contrast, the higher the got milk flour, the higher the fat $(p=0.000)$, carbohydrate $(p=0.000)$, energy $(p=0.000)$ and energy density $(p=0.013)$. Formula P3 has the highest viscosity (1.93 $\pm 0.039 \mathrm{cP})$ and protein (9.66 $\pm 0.16 \%)$, while P1 has the highest fat $(27.33 \pm 0.15 \%)$, carbohydrate $(65.97 \pm 0.23 \%)$, energy $(1.175 \pm 3.04 \mathrm{kkal})$, energy density $(1.17 \pm 0.00 \mathrm{kkal} / \mathrm{ml})$, and protein digestibility $(45.90 \pm 1.49 \%)$ among others. However, there is no effect of different formula toward protein digestibility ( $p=0.116)$. Organoleptic properties showed that the higher the got milk flour, the higher its acceptance in all aspect including color $(p=0.046)$, flavor $(p=0.000)$, taste $(p=0.009)$ dan texture $(p=0.002)$.

Conclusion: P1 was the best formula due to its level of viscosity, fat, energy, protein and energy density that meet requirements according to European Society for Clinical Nutrition and Metabolism (ESPEN). P1 also has the highest protein digestibility, and have the highest score of all organoleptic parameters.

Keywords: enteral formula; chronic liver disease; soybean flour; goat milk flour

\section{ABSTRACT}

Latar Belakang: Pasien dengan gangguan hati berisiko malnutrisi karena gangguan absorpsi, adanya hipermetabolik, dan asupan oral kurang. Terapi diet enteral berbasis tepung kedelai dan tepung susu kambing bermanfaat sebagai alternatif formula untuk pasien gangguan hati karena mengandung Branched-Chain Amino Acids (BCAA) dan Medium-chain Triglyceride (MCT) tinggi.

Tujuan : untuk mengkaji viskositas, kandungan zat gizi, daya cerna protein dan organoleptik formula enteral "Hepatogomax" untuk penyakit hati berbasis tepung kedelai dan tepung susu kambing.

Metode: Penelitian ini merupakan penelitian eksperimental dengan 3 taraf perlakuan yaitu variasi perbandingan tepung kedelai dan tepung susu kambing dengan P1 (45:55), P2 (50:50), P3 (55: 45). Analisis nilai viskositas, kadar lemak, karbohidrat, dan kandungan energi diuji dengan One Way Anova dilanjutkan uji Tukey, sedangkan analisis kadar protein, daya cerna protein, dan densitas energi menggunakan Kruskal-Wallis dilanjutkan Mann-Whitney. Analisis organoleptik menggunakan Friedman dilanjutkan Wilcoxon.

Hasil: Makin tinggi perbandingan tepung kedelai, makin tinggi viskositas formula $(p=0,000)$ dan protein $(p=0,007)$ pada formula. Sebaliknya, semakin tinggi perbandingan tepung susu kambing, maka semakin tinggi kandungan lemak ( $p=0,000)$, karbohidrat $(p=0,000)$, kalori $(p=0,000)$ dan densitas energi $(p=0,013)$. P3 memiliki viskositas $(1,93 \pm 0,039 c P)$, dan protein

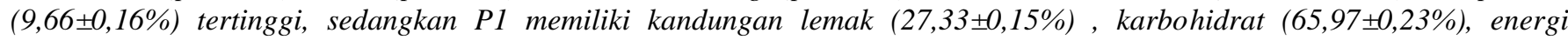
$(1,175 \pm 3,04 \mathrm{kkal})$, densitas energi $(1,17 \pm 0,00 \mathrm{kkal} / \mathrm{ml})$, dan daya cerna $(45,90 \pm 1,49 \%)$ tertinggi dibanding formula lain. Tidak ada pengaruh perbandingan kandungan formula terhadap daya cerna protein $(p=0,116)$. Pada uji organoleptik, makin tinggi kandungan susu kambing, makin tinggi penerimaan pada aspek warna $(p=0,046)$, aroma $(p=0,000)$, rasa $(p=0,009)$ dan tekstur $(p=0,002)$.

Simpulan: Formula terbaik adalah P1 karena memiliki kadar lemak, energi, protein, densitas energi menurut European Society for Clinical Nutrition and Metabolism (ESPEN), serta memiliki nilai penerimaan tertinggi diantara formula lain. Formula P1 juga memiliki daya cerna protein dan skor uji penerimaan yang paling tinggi dibandingkan formula lain.

Kata Kunci: formula enteral; penyakit gangguan hati; tepung kedelai; tepung susu kambing

Departemen Ilmu Gizi, Fakultas Kedokteran, Universitas Diponegoro. Jl. Prof. Sudarto SH, Tembalang, Semarang, Jawa Tengah 50275, Indonesia

*Korespondensi : E-mail: choirun.nissa@live.undip.ac.id 


\section{PENDAHULUAN}

Sirosis hati merupakan salah satu penyebab utama beban kesehatan di dunia dengan angka morbiditas dan mortalitas yang tinggi. ${ }^{1}$ Kematian karena sirosis hati secara global meningkat dari $1,54 \%$ pada tahun 1980 menjadi $1,95 \%$ pada tahun $2010 .^{2,3}$ Tingginya angka kematian pasien sirosis hati disebabkan karena malnutrisi. Prevalensi malnutrisi pada pasien sirosis hati mencapai $65-90 \% .^{4,5}$ Bahkan pasien sirosis dengan malnutrisi dapat meningkatkan kejadian komplikasi dan angka kematian sebesar 71,3\% dan 41,4\% dibandingkan pasien tidak malnutrisi sebesar $38,2 \%$ dan $18,2 \% .^{6}$ Malnutrisi terjadi karena beberapa faktor, diantaranya asupan kurang, gangguan absorpsi dan hipermetabolik., ${ }^{4,8}$ Guna mencegah keparahan malnutrisi akibat tidak menerima zat gizi yang cukup melalui makanan secara oral, penggunaan makanan enteral dapat dipertimbangkan..$^{9,10}$

Formula enteral penyakit hati di Indonesia pada umumnya dalam bentuk formula enteral komersial, dimana harganya relatif mahal sehingga memperbesar biaya perawatan pasien. Saat ini formula enteral rumah sakit (FERS) sudah banyak dikembangkan namun umur simpannya yang relatif pendek karena bahan cair. ${ }^{11}$ Inovasi formula yang lebih tahan lama dengan harga yang lebih murah sangat diperlukan yaitu melalui FERS berbasis bubuk. Pembuatan FERS perlu mempertimbangkan viskositas supaya dapat melewati pipa sonde. ${ }^{12}$

Persyaratan diet pada penyakit gangguan hati menurut European Society for Clinical Nutrition and Metabolism (ESPEN) adalah diberikan energi 35-40 $\mathrm{kkal} / \mathrm{kgBB} / \mathrm{hari}$, protein $1-1,5 \mathrm{~g} / \mathrm{kgBB} / \mathrm{hari}$ tanpa ensefalopati hepatikum atau 0,6-0,8 $\mathrm{g} / \mathrm{kgBB} / \mathrm{hari}$ dengan ensefalopati hepatikum, karbohidrat 45-65\%, dan lemak 25-30\%. ${ }^{5,13,14}$ Protein diutamakan dari protein nabati dan produk susu karena lebih mudah ditoleransi serta rendah Aromatic Amino Acids (AAA) dan amonia daripada protein ikan dan daging. Protein nabati mengandung serat yang dapat mempercepat pengeluaran amonia melalui feses dan mengandung Branched-Chain Amino Acids (BCAA) tinggi. ${ }^{7,9}$

Kemampuan hati pada pasien dengan penyakit hati untuk menerima protein dan kemampuan deaminasi menurun sehingga terjadi penurunan BCAA dan peningkatan AAA. BCAA terutama leusin mengatur sintesis albumin yang dapat meningkatkan kadar serum albumin dan status gizi. ${ }^{15}$ Berbeda pada metabolisme BCAA yang tidak bergantung pada fungsi hati dan terjadi terutama di otot, metabolisme AAA bergantung pada fungsi hati dan terjadi terutama di hati ${ }^{10} \mathrm{BCAA}$ dan AAA bersaing dengan prekusor serotonin yaitu triptofan sehingga penurunan BCAA meningkatkan penyerapan triptofan di otak. Penyerapan triptofan yang lebih besar menyebabkan ketidakseimbangan sintesis neurotransmiter di otak, sehingga terjadi gangguan kesadaran yang merupakan karakteristik ensefalopati hepatik. $^{5}$

Diet penyakit hati selain dilihat dari segi kuantitas (tinggi BCAA) juga harus memperhatikan nilai gizi protein dari segi kualitas atau mutu. Kualitas protein dapat ditentukan oleh daya cerna yang didefinisikan sebagai efektivitas absorpsi protein oleh tubuh. ${ }^{16}$ Salah satu bahan makanan sumber protein nabati yang tinggi BCAA dan daya cerna protein adalah kedelai. Produk yang mengandung kedelai umumnya bergizi tinggi dan mengandung protein yang mudah dicerna. World Health Organization (WHO) telah menetapkan bahwa jika dikonsumsi sesuai anjuran protein harian, kedelai mengandung jumlah asam amino esensial yang cukup dan dapat disejajarkan dengan protein hewani. ${ }^{17}$ Kedelai dapat dimodifikasi dalam bentuk tepung karena kandungan protein yang lebih tinggi dari produk segarnya, menghilangkan cita rasa langu (beany), meningkatkan daya cerna dan meningkatkan lama simpan. ${ }^{18}$

Lemak juga dibutuhkan untuk sumber kalori dan keperluan metabolisme pasien sirosis. Malabsorpsi lemak merupakan salah satu gangguan yang terjadi pada pasien sirosis akibat defisiensi asam empedu sehingga mengganggu absorpsi asam lemak rantai panjang. ${ }^{5}$ Keadaan ini dapat diatasi dengan pemberian lemak dalam bentuk Medium-chain Triglyceride (MCT). Salah satu bahan makanan yaitu susu kambing mengandung MCT tinggi sekitar 35\% dibandingkan susu sapi $17 \% .{ }^{19,20}$ Susu kambing mempunyai kelebihan dibandingkan susu sapi yaitu kandungan lemak yang mudah dicerna, protein lebih mudah larut dan diserap, dan rendah memicu alergi. ${ }^{19,21-23}$ Rata-rata komposisi asam amino pada susu kambing menunjukkan 6 dari 10 asam amino lebih tinggi daripada susu sapi terutama 2 BCAA yaitu isoleusin lebih tinggi $4 \%$ dan valin lebih tinggi $9 \% .20,21$

Selain memperhatikan dari segi kandungan gizi dan daya cernanya, produk formula enteral juga harus memperhatikan penerimaan serta kesukaan konsumen terhadap warna, rasa, aroma dan tekstur melalui pengujian secara organoleptik. Uji organoleptik memiliki relevansi yang tinggi dengan mutu produk karena berhubungan langsung dengan selera konsumen. ${ }^{24-26}$ Berdasarkan kelebihan tepung kedelai dan tepung susu kambing maka peneliti tertarik untuk mengkaji mengenai viskositas, kandungan zat gizi, daya cerna protein dan organoleptik formula enteral penyakit hati berbasis tepung kedelai dan tepung susu kambing dengan nama "Hepatogomax".

\section{BAHAN DAN METODE}

Penelitian yang dilakukan termasuk dalam bidang gizi dan pangan serta merupakan penelitian 
eksperimental menggunakan 3 taraf perlakuan, yaitu variasi perbandingan tepung kedelai dan tepung susu kambing. Penelitian dilaksanakan bulan Juli-Agustus 2018 di Laboratorium Terpadu Universitas Diponegoro untuk uji kandungan zat gizi dan viskositas, Laboratorium Analisa CV Chem-Mix Pratama Yogyakarta untuk uji daya cerna protein, dan di lingkungan Ilmu Gizi Universitas Diponegoro untuk uji organoleptik.

Bahan yang digunakan dalam penelitian ini adalah tepung kedelai "Kusuka Ubiku", tepung susu kambing "Skygoat", virgin coconut oil (VCO) "Al Afiat", maltodekstrin, dan gula pasir yang dihaluskan. Penelitian ini terbagi atas penelitian pendahuluan dan penelitian utama. Penelitian pendahuluan dilakukan untuk mengetahui kandungan zat gizi yang terdapat dalam tepung kedelai. Sebelum melakukan penelitian utama, dilakukan penentuan taraf perlakuan dengan melakukan estimasi perhitungan terhadap bahan yang digunakan berdasarkan persyaratan diet hati dengan memasukkan pada program di microsoft office excel. Persyaratan diet penyakit hati menurut European Society for Clinical Nutrition and Metabolism (ESPEN) adalah energi $35-40 \mathrm{kkal} / \mathrm{kgBB} / \mathrm{hari}$, protein $1-1,5$ $\mathrm{g} / \mathrm{kgBB} /$ hari tanpa ensefalopati hepatikum atau $0,6-0,8$ $\mathrm{g} / \mathrm{kgBB} /$ hari dengan ensefalopati hepatikum, karbohidrat 45-65\%, dan lemak 25-30\%. Formulasi bahan dapat dilihat pada Tabel 1 dengan perbandingan tepung kedelai dan tepung susu kambing yaitu P1 (45:55), P2 (50:50), P3 (55:45).

Tabel 1. Formulasi Makanan Enteral Penyakit Hati Modifikasi

\begin{tabular}{lccc}
\hline \multicolumn{1}{c}{ Bahan penyusun } & $\begin{array}{c}\text { P1 } \\
(\mathbf{4 5 : 5 5 )}\end{array}$ & $\begin{array}{c}\text { P2 } \\
\mathbf{( 5 0 : 5 0 )}\end{array}$ & $\begin{array}{c}\text { P3 } \\
\mathbf{( 5 5 : 4 5 )}\end{array}$ \\
\hline Tepung kedelai $(\mathrm{g})$ & 63 & 70 & 77 \\
Tepung susu kambing $(\mathrm{g})$ & 77 & 70 & 63 \\
Virgin coconut oil $(\mathrm{g})$ & 7 & 7 & 7 \\
Gula pasir halus $(\mathrm{g})$ & 45 & 45 & 45 \\
Maltodekstrin $(\mathrm{g})$ & 70 & 70 & 70 \\
Total $(\mathrm{g})$ & 262 & 262 & 262 \\
\hline
\end{tabular}

Pembuatan formula enteral dimulai dengan menimbang bahan-bahan sesuai dengan masing-masing perbandingan. Bahan kering seperti tepung kedelai, tepung susu kambing, maltodekstrin dan gula halus dicampurkan secara manual selama 3 menit. VCO ditambahkan ke dalam campuran bahan kering dan diaduk selama 2 menit. Semua bahan yang sudah diaduk secara manual, diaduk kembali menggunakan mixer selama 8 menit supaya tercampur homogen. Formula enteral yang sudah tercampur homogen dilakukan pengayakan untuk menghasilkan formula yang lebih halus.

Masing-masing perbandingan formula enteral dilakukan analisis uji viskositas, kandungan zat gizi, dan daya cerna protein dengan 2 kali pengulangan secara duplo serta organoleptik dengan 1 kali pengujian. Uji viskositas menggunakan metode gravimetri dengan alat viskometer ostwald. Kandungan zat gizi meliputi kadar protein menggunakan metode kjeldahl, kadar lemak menggunakan metode soxhlet, kadar karbohidrat menggunakan metode by difference. Kandungan energi diperoleh dengan perhitungan $4 \mathrm{kkal} / \mathrm{g}$ protein +9 $\mathrm{kkal} / \mathrm{g}$ lemak $+4 \mathrm{kkal} / \mathrm{g}$ karbohidrat. Setelah kandungan energi diketahui, maka densitas energi diperoleh dengan membagi kandungan energi dengan volume. Daya cerna protein menggunakan metode in-vitro secara enzimatis dengan enzim pepsin. Uji organoleptik meliputi parameter warna, aroma, rasa, dan tekstur dengan 5 skala yaitu $1=$ sangat tidak suka, $2=$ tidak suka, $3=$ netral, 4=suka, 5=sangat suka. Penilaian organoleptik dilakukan pada 25 panelis agak terlatih yaitu mahasiswa Ilmu Gizi Fakultas Kedokteran Universitas Diponegoro.

Data nilai viskositas, kadar lemak, karbohidrat dan kandungan energi yang terdistribusi normal dianalisis dengan uji One Way Anova dilanjut uji post hoc Tukey. Adapun data yang tidak terdistribusi normal (kadar protein, daya cerna protein dan densitas energi) dianalisis dengan uji Kruskal-Wallis dan uji lanjut Mann-Whitney untuk mengetahui beda nyata antar perlakuan. Uji organoleptik dianalisis menggunakan uji beda non parametrik Friedman dengan uji lanjut Wilcoxon.

\section{HASIL}

\section{Viskositas}

Hasil analisis nilai viskositas formula enteral Hepatogomax dapat dilihat pada Tabel 2. Analisis data dengan uji One Way Anova dilanjutkan uji Tukey menunjukkan semakin tinggi perbandingan tepung kedelai, semakin tinggi viskositas formula Hepatogomax. Nilai viskositas juga telah mencapai target ketentuan formula enteral berdasar American Dietetic Association dimana nilai yang memenuhi syarat adalah $1-50 \quad \mathrm{cP}^{30}$ Nilai viskositas tertinggi terdapat pada formula enteral P3 yaitu $1,93 \pm 0,028 \mathrm{cP}$ dengan perbandingan tepung kedelai dan tepung susu kambing 55:45.

\section{Kandungan Zat Gizi dan Daya Cerna Protein}

Hasil analisis kandungan zat gizi dan daya cerna protein formula enteral Hepatogomax dapat dilihat pada Tabel 3. 
Tabel 2. Viskositas Formula Enteral Hepatogomax

\begin{tabular}{|c|c|c|c|c|}
\hline & \multicolumn{3}{|c|}{ Formula Enteral (Tp.Kedelai : Tp.Susu Kambing) } & \multirow{2}{*}{$p$} \\
\hline & P1 (45:55) & P2 (50:50) & P3 (55:45) & \\
\hline Viskositas (cp) & $1,45 \pm 0,025^{\mathrm{c}}$ & $1,74 \pm 0,028^{\mathrm{b}}$ & $1,93 \pm 0,039^{\mathrm{a}}$ & $0,000 *$ \\
\hline
\end{tabular}

Keterangan: Angka yang diikuti dengan huruf superscript berbeda (a,b,c) menunjukkan beda nyata, * Uji One Way Anova

Tabel 3. Kandungan Zat Gizi Dan Daya Cerna Protein Formula Enteral Hepatogomax

\begin{tabular}{|c|c|c|c|c|c|c|}
\hline \multirow{2}{*}{$\begin{array}{c}\text { Formula } \\
\text { Enteral } \\
\text { (Tp.Kedelai: } \\
\text { Tp.Susu } \\
\text { Kambing) }\end{array}$} & \multicolumn{6}{|c|}{ Rerata Kandungan Zat Gizi/1000 ml Formula } \\
\hline & $\begin{array}{c}\text { Lemak } \\
(\%)\end{array}$ & $\begin{array}{l}\text { Protein } \\
(\%)\end{array}$ & $\begin{array}{c}\text { Karbohidrat } \\
(\%)\end{array}$ & $\begin{array}{c}\text { Energi } \\
\text { (kkal) }\end{array}$ & $\begin{array}{c}\text { Densitas } \\
\text { Energi } \\
(\mathbf{k k a l} / \mathbf{m l})\end{array}$ & $\begin{array}{c}\text { Daya Cerna } \\
\text { Protein } \\
(\%)\end{array}$ \\
\hline P1 (45:55) & $27,33 \pm 0,15^{\mathrm{c}}$ & $6,70 \pm 0,10^{c}$ & $65,97 \pm 0,23^{b}$ & $1.175 \pm 3,04^{\mathrm{b}}$ & $1,17 \pm 0,00^{\mathrm{b}}$ & $53,44 \pm 4,03^{a}$ \\
\hline P2 (50:50) & $25,91 \pm 0,05^{\mathrm{b}}$ & $8,71 \pm 0,06^{\mathrm{b}}$ & $65,38 \pm 0,11^{\mathrm{a}}$ & $1.157 \pm 1,63^{\mathrm{a}}$ & $1,15 \pm 0,00^{\mathrm{a}}$ & $47,12 \pm 5,95^{\mathrm{a}}$ \\
\hline \multirow[t]{2}{*}{ P3 (55:45) } & $25,05 \pm 0,09^{\mathrm{a}}$ & $9,66 \pm 0,16^{\mathrm{a}}$ & $65,29 \pm 0,10^{\mathrm{a}}$ & $1.151 \pm 5,39^{\mathrm{a}}$ & $1,15 \pm 0,00^{\mathrm{a}}$ & $45,90 \pm 1,49^{\mathrm{a}}$ \\
\hline & $\mathrm{p}=0,000^{*}$ & $\mathrm{p}=0,007 * *$ & $\mathrm{p}=0,000 *$ & $\mathrm{p}=0,000 *$ & $\mathrm{p}=0,013^{* *}$ & $\mathrm{p}=0,116^{* *}$ \\
\hline
\end{tabular}

Keterangan : Angka yang diikuti dengan huruf superscript berbeda (a,b,c) menunjukkan beda nyata; *Uji One Way Anova **Uji Kruskal-Wallis

Hasil uji statistik menunjukkan di satu sisi, kandungan protein semakin meningkat seiring dengan meningkatnya rasio tepung kedelai. Di sisi lain, kandungan lemak, karbohidrat dan densitas energi meningkat seiring dengan semakin tingginya rasio tepung susu kambing. Selain itu, tidak ada pengaruh rasio formula terhadap daya cerna protein.

Formula enteral P1 dengan perbandingan tepung kedelai dan tepung susu kambing 45:55 memiliki kadar lemak, kadar karbohidrat, kandungan energi, densitas energi dan daya cerna protein tertinggi namun kadar protein terendah. Berbeda dengan P1, formula enteral P3 dengan perbandingan tepung kedelai dan tepung susu kambing 55:45 memiliki kadar lemak, kadar karbohidrat, kandungan energi, densitas energi dan daya cerna protein terendah namun kadar protein tertinggi.

Berdasarkan persyaratan zat gizi makanan enteral penyakit hati menurut European Society for Clinical Nutrition and Metabolism (ESPEN), kandungan energi; densitas energi; dan kadar lemak pada ketiga formula percobaan telah memenuhi syarat, sedangkan untuk kadar karbohidrat pada ketiga formula tidak memenuhi syarat karena melebihi standar. Kadar protein formula P1 dan P2 telah memenuhi syarat untuk pasien penyakit hati dengan ensefalopati hepatikum $(0,6-0,8$ $\mathrm{g} / \mathrm{kgBB} /$ hari atau $6-9,14 \%$ ). Sebaliknya, formula P3 tidak memenuhi syarat karena melebihi standar untuk pasien penyakit hati dengan ensefalopati hepatikum $(0,6-0,8 \mathrm{~g} / \mathrm{kgBB} / \mathrm{hari}$ atau $6-9,14 \%)$. Lebih lanjut lagi, berdasarkan persyaratan kadar protein untuk pasien penyakit hati tanpa ensefalopati hepatikum (1-1,5 $\mathrm{g} / \mathrm{kgBB} / \mathrm{hari}$ atau $10-17,14 \%$ ), ketiga formula percobaan memiliki kadar protein yang masih belum memenuhi persyaratan. ${ }^{13}$

\section{Organoleptik}

Hasil analisis organoleptik tingkat kesukaan formula enteral Hepatogomax dapat dilihat pada Tabel 4. Parameter organoleptik yang dinilai adalah warna, aroma, rasa, dan tekstur. Analisis statistik dengan uji beda non parametrik Friedman, didapatkan hasil bahwa perbandingan tepung kedelai dan tepung susu kambing berpengaruh terhadap warna, aroma, rasa, dan tekstur formula enteral Hepatogomax. Analisis lebih lanjut dengan uji Wilcoxon menunjukkan bahwa warna, aroma, dan rasa formula P1 berbeda signifikan dengan formula lainnya. Tekstur formula enteral P1 dan P3 menunjukkan perbedaan signifikan berdasarkan uji lanjut Wilcoxon. Formula enteral P1 secara keseluruhan merupakan formula yang paling disukai dengan nilai rata-rata tertinggi pada semua parameter baik warna $(4,12 \pm 0,72)$, aroma $(3,80 \pm 0,70)$, rasa $(3,80 \pm 0,96)$ maupun tekstur $(3,96 \pm 0,67)$. Selanjutnya diikuti oleh formula enteral P2 dan P3.

Tabel 4. Rerata Hasil Analisis Uji Organoleptik Formula Enteral Hepatogomax

\begin{tabular}{|c|c|c|c|c|}
\hline $\begin{array}{c}\text { Formula Enteral } \\
\text { (Tp.Kedelai : Tp.Susu } \\
\text { Kambing) } \\
\end{array}$ & Warna & Aroma & Rasa & Tekstur \\
\hline $\mathrm{P} 1(45: 55)$ & $4,12 \pm 0,72^{b}($ suka $)$ & $3,80 \pm 0,70^{\mathrm{b}}$ (netral) & $3,80 \pm 0,96^{\mathrm{b}}$ (netral) & $3,96 \pm 0,67^{b}$ (netral) \\
\hline P2 (50:50) & $3,64 \pm 0,63^{\mathrm{a}}$ (netral) & $2,60 \pm 0,81^{\mathrm{a}}$ (tidak suka) & $3,24 \pm 0,97^{\mathrm{a}}$ (netral) & $3,52 \pm 0,82^{\mathrm{ab}}$ (netral) \\
\hline P3 $(55: 45)$ & $\begin{array}{c}3,56 \pm 0,76^{\mathrm{a}} \text { (netral) } \\
\mathrm{p}=0,046^{*}\end{array}$ & $\begin{array}{c}2,52 \pm 0,77^{\mathrm{a}} \text { (tidak suka) } \\
\mathrm{p}=0,000^{*}\end{array}$ & $\begin{array}{c}3,12 \pm 1,13^{\mathrm{a}} \text { (netral) } \\
\mathrm{p}=0,009^{*}\end{array}$ & $\begin{array}{c}3,24 \pm 0,77^{\mathrm{a}} \text { (netral) } \\
\mathrm{p}=0,002 *\end{array}$ \\
\hline
\end{tabular}




\section{PEMBAHASAN}

\section{Viskositas}

Viskositas adalah suatu cara yang digunakan untuk menunjukkan berapa daya dari aliran yang diberikan oleh suatu cairan. ${ }^{12}$ Peningkatan viskositas dipengaruhi oleh beberapa faktor antara lain penurunan suhu, peningkatan kandungan protein, ukuran lemak yang besar, tingginya konsentrasi larutan, peningkatan tekanan dan berat molekul terlarut. ${ }^{27-29}$

Viskositas ketiga formula enteral Hepatogomax berkisar antara 1,45-1,93 cp. Standar viskositas untuk formula enteral berdasarkan American Dietetic Association adalah 1-50 cP, ketiga formula enteral Hepatogomax telah memenuhi syarat. ${ }^{30}$ Peningkatan perbandingan tepung kedelai cenderung membuat viskositas formula enteral Hepatogomax semakin meningkat.

Faktor yang mempengaruhi viskositas formula enteral Hepatogomax adalah adanya pembentukan gel pada campuran karbohidrat dan protein yang diakibatkan proses gelatinisasi pati dan gelasi protein. ${ }^{31}$ Protein dapat membentuk gel dengan adanya asam, pemanasan, atau aktivitas enzim. Mekanisme gelasi pada formula enteral Hepatogomax terjadi akibat proses pemanasan pada saat penyeduhan dengan air panas, molekul protein akan saling berinteraksi satu dengan lainnya sehingga terbentuk formasi gel.

Protein kedelai sebagian besar (85-95\%) terdiri dari globulin. Globulin merupakan protein yang tidak larut air dan mudah terkoagulasi karena pemanasan. Oleh karena itu, semakin tinggi komposisi tepung kedelai menyebabkan viskositas formula enteral Hepatogomax semakin tinggi. ${ }^{28,29,32}$ Peningkatan kadar protein juga menyebabkan meningkatnya nilai viskositas dimana pada formula enteral P3 yang mengandung kadar protein paling tinggi $(9,66 \%)$ diantara formula lainnya juga memiliki nilai viskositas yang paling tinggi yaitu $1,93 \mathrm{cp}$.

Selain itu susu kambing juga berpengaruh terhadap nilai viskositas karena memiliki ukuran globula lemak yang lebih kecil yaitu sebesar $2 \mu \mathrm{m}$ dibandingkan dengan susu sapi sekitar 2,5-3,5 $\mu \mathrm{m}$. Ukuran partikel globula lemak yang kecil menyebabkan susu kambing lebih homogen dan lebih terlarut sehingga semakin tinggi komposisi tepung susu kambing maka viskositasnya menjadi rendah. ${ }^{21,23}$

\section{Kandungan Zat Gizi dan Daya Cerna Protein Kadar Lemak}

Sumber lemak formula enteral Hepatogomax berasal dari minyak kelapa murni, tepung kedelai dan tepung susu kambing. Lemak nabati terutama kedelai banyak mengandung fosfolipid seperti lesitin (phosphatidylcholines) yang dapat meningkatkan absorpsi zat gizi ke dalam sel melalui fungsinya sebagai pelindung membran sel. ${ }^{33}$ Virgin coconut oil (VCO) digunakan karena merupakan salah satu sumber triasilgliserol rantai sedang (medium-chain triacylglicerol/MCT) yang memiliki sifat mudah dicerna meskipun tidak ada asam empedu serta menyediakan sumber energi yang cepat dan tidak disimpan sebagai lemak tubuh. ${ }^{34}$ Hal ini disebabkan karena molekul MCT lebih kecil daripada long chain triacylglicerols (LCT) yang dapat memfasilitasi aksi lipase pankreas sehingga akan terhidrolisis lebih cepat dan lebih sempurna daripada lemak lainnya. ${ }^{35}$ Susu kambing juga mengandung MCT yang tinggi yakni 2 kali lipat lebih banyak atau sekitar 35\% dibandingkan

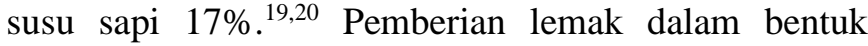
MCT berperan untuk mengatasi gangguan malabsorpsi lemak pada pasien sirosis hati. ${ }^{5}$

Formula enteral Hepatogomax pada ketiga perbandingan memiliki kadar lemak berkisar antara 25$27 \%$ dimana ketiga formula telah memenuhi persyaratan diet penyakit hati menurut European Society for Clinical Nutrition and Metabolism (ESPEN) yaitu $25-30 \%$ dari total energi. ${ }^{13}$ Kadar lemak tertinggi terdapat pada formula enteral P1 dengan perbandingan tepung susu kambing yang lebih banyak. Hal ini disebabkan kadar lemak tepung susu kambing lebih tinggi dari pada tepung kedelai. Setiap seratus gram tepung susu kambing dan tepung kedelai masingmasing mengandung $25 \mathrm{~g}$ dan 19,43 g lemak.

\section{Kadar Protein}

Kebutuhan protein menurut ESPEN adalah 0,6$0,8 \mathrm{~g} / \mathrm{kgBB} / \mathrm{hari} \quad(6-9,14 \%)$ dengan ensefalopati hepatikum atau $1-1,5 \mathrm{~g} / \mathrm{kgBB} / \mathrm{hari}(10-17,14 \%)$ tanpa ensefalopati hepatikum. ${ }^{5}$ Pembatasan protein tidak direkomendasikan pada pasien sirosis hati karena dapat menyebabkan peningkatan katabolisme protein yang dapat memperburuk komplikasi ensefalopati hepatik karena pelepasan amonia (hasil sampingan dari katabolisme protein yang bersifat toksik untuk tubuh) ${ }^{5,9}$ Asupan protein diutamakan dari protein nabati dan produk susu karena lebih mudah ditoleransi, rendah Aromatic Amino Acid (AAA) dan amonia, tinggi Branched-Chain Amino Acids (BCAA) dibanding protein ikan dan daging. ${ }^{7,9}$

BCAA adalah asam amino esensial untuk sintesis protein, protein turnover, dan regulasi metabolisme energi. BCAA terdiri dari asam amino leusin, isoleusin, dan valin sedangkan AAA terdiri dari asam amino triptofan, fenilalanin, dan tirosin. Amonia dan AAA secara normal dimetabolisme dan/atau didetoksifikasi oleh hati. Pasien dengan penyakit hati lanjut, AAA terakumulasi sebagai hasil dari gangguan fungsi hepatosit. Pasien sirosis mempunyai rasio BCAA:AAA yang rendah. BCAA menurun karena diambil oleh sel otot skeletal sebagai substrat energi atau degradasi amonia, sedangkan AAA meningkat karena gangguan kapasitas hepatosit pada deaminasi. $^{5}$ 
Kadar protein ketiga formula enteral Hepatogomax berkisar antara 6,70-9,66\%, kadar protein formula P1 dan P2 telah memenuhi syarat untuk pasien penyakit hati dengan ensefalopati hepatikum sedangkan formula P3 melebihi syarat. Berdasarkan persyaratan untuk pasien penyakit hati tanpa ensefalopati hepatikum, ketiga formula percobaan memiliki kadar protein dibawah persyaratan. Meningkatnya kadar protein seiring dengan meningkatnya perbandingan tepung kedelai. Berdasarkan penelitian pendahuluan, kadar protein tepung kedelai $(36,5 \mathrm{~g} / 100 \mathrm{~g})$ lebih tinggi dibandingkan tepung susu kambing $(5 \mathrm{~g} / 100 \mathrm{~g})$.

\section{Kadar Karbohidrat}

Karbohidrat merupakan senyawa organik yang terbentuk dari atom karbon, oksigen dan hidrogen. Karbohidrat telah menjadi sumber energi utama untuk metabolisme pada manusia, dimana jumlah energi yang dapat dihasilkan oleh 1 gram karbohidrat adalah 4 kkal. Selain sebagai sumber energi, karbohidrat juga berfungsi sebagai cadangan makanan dan pemberi rasa manis pada makanan. ${ }^{36}$ Sumber karbohidrat formula enteral Hepatogomax berasal dari gula, maltodekstrin, tepung susu kambing dan tepung kedelai.

Persentase karbohidrat ketiga formula enteral Hepatogomax berkisar antara 65,29-65,97\%, atau telah melebihi persyaratan ESPEN, dimana persyaratan tersebut adalah $45-65 \% .{ }^{13}$ Perbedaan kadar karbohidrat pada masing-masing formula disebabkan hasil penelitian pendahuluan dimana kadar karbohidrat pada tepung susu kambing lebih tinggi (40g/100g) dibandingkan tepung kedelai $(37,8 \mathrm{~g} / 100 \mathrm{~g})$. Formula P1 memiliki perbandingan tepung susu kambing yang lebih banyak dibandingkan tepung kedelai sehingga formula P1 mengandung kadar karbohidrat paling tinggi dibandingkan formula lainnya.

Asupan karbohidrat yang cukup berguna untuk membantu mencegah hipoglikemia karena gangguan sintesis glikogen dan penyimpanan glikogen yang terbatas di hati akibat sirosis hati. Asupan karbohidrat yang berlebih mengakibatkan peningkatan $\mathrm{CO}_{2}$ yang dapat menimbulkan sesak nafas. ${ }^{5}$

\section{Kandungan Energi dan Densitas Energi}

Kandungan energi ketiga formula enteral Hepatogomax per $1000 \mathrm{ml}$ berkisar antara 1151-1175 kkal, sehingga densitas energi yang dihasilkan berkisar antara 1,15-1,17 kkal/ml. Densitas energi formula Hepatogomax telah sesuai dengan syarat formula enteral yaitu antara 1-2 kkal/ml. Densitas energi yang tinggi untuk pasien penyakit hati berfungsi untuk mencegah kejadian malnutrisi serta adanya pembatasan cairan untuk mencegah ascites dan edema. ${ }^{10,37}$

Kadar lemak berbanding lurus dengan kepadatan energi suatu formula. Kandungan karbohidrat, lemak, dan protein suatu bahan makanan menentukan nilai energinya. Lemak menghasilkan $9 \mathrm{kkal} / \mathrm{g}$, dimana lebih tinggi daripada karbohidrat dan protein yang menghasilkan $4 \mathrm{kkal} / \mathrm{g} .{ }^{10}$ Penurunan kandungan energi dan densitas energi pada formula Hepatogomax berkaitan dengan menurunnya kadar lemak seiring dengan peningkatan perbandingan tepung kedelai. Formula P3 dengan kadar lemak yang paling rendah juga memiliki kandungan energi yang paling rendah dibandingkan formula lainnya. Berdasarkan hal tersebut, maka dapat diartikan bahwa penurunan kadar lemak pada formula enteral berpengaruh pada penurunan kandungan energi dan kepadatan energi.

\section{Daya Cerna Protein}

Mutu protein suatu bahan pangan ditentukan oleh kandungan asam amino esensial dan daya cerna protein. Daya cerna protein adalah besarnya kemampuan suatu protein untuk dihidrolisis menjadi asam-asam amino oleh enzim pencernaan (protease) yang selanjutnya akan diserap dan digunakan oleh tubuh. ${ }^{38}$ Apabila daya cerna protein tinggi maka protein dapat dihidrolisis dengan baik menjadi asam-asam amino sehingga dapat diserap oleh tubuh, sedangkan apabila daya cerna protein rendah maka protein sulit dihidrolisis menjadi asam amino sehingga jumlah asam amino yang dapat diserap tubuh rendah karena sebagian besar akan dibuang melalui feses. ${ }^{16}$ Daya cerna protein pada suatu bahan pangan dipengaruhi oleh adanya senyawa antigizi (asam fitat, tanin, hemaglutinin, protease inhibitor), proses pengolahan (denaturasi protein, reaksi maillard), dan reaksi antara protein dengan senyawa lain (polifenol, karbohidrat, lemak, serat). ${ }^{39-41}$

Umumnya protein hewani (daging, ikan, susu, telur) merupakan protein yang bernilai gizi tinggi, kecuali gelatin. Sebaliknya, protein nabati daya cernanya lebih rendah dan kekurangan salah satu/lebih asam amino esensial. Contoh protein serealia (beras, terigu) kekurangan asam amino lisin, sedangkan protein kacang-kacangan (kedelai) kekurangan asam amino belerang (metionin). ${ }^{38}$

Daya cerna protein ketiga formula enteral Hepatogomax berkisar 45,90-53,44\%. Formula P1 memiliki daya cerna protein tertinggi sebesar $53,44 \%$ dengan jumlah tepung kedelai yang sedikit dibandingkan tepung susu kambing. Hal ini menunjukkan adanya penurunan daya cerna protein formula enteral seiring peningkatan tepung kedelai. Protein yang masuk ke dalam tubuh tidak seluruhnya dapat dicerna. Protein hewani yaitu susu kambing dapat dihidrolisis hampir sempurna menjadi asam-asam amino, sedangkan protein nabati yaitu tepung kedelai umumnya tidak sempurna dicerna karena protein dilindungi oleh pelindung selulosa dan polisakarida. ${ }^{42}$ Menurut WHO, daya cerna protein susu bubuk dan tepung kedelai pada manusia masing-masing adalah $94 \%$ dan $71,8 \% .^{43}$

Penurunan daya cerna protein formula enteral Hepatogomax yang seiring dengan peningkatan jumlah tepung kedelai disebabkan karena adanya senyawa 
antigizi dan serat pangan. Telah diketahui bahwa paling sedikit ada 5-6 macam inhibitor protease pada kedelai. Protease inhibitor adalah senyawa yang dapat menghambat aktivitas enzim proteolitik, enzim yang diperlukan untuk mencerna protein dalam lambung. Kandungan hemaglutinin, tanin, asam fitat yang terdapat pada kedelai juga menyebabkan rendahnya daya cerna protein. Asam fitat dapat mengikat protein dan mineral tertentu seperti magnesium, kalsium, dan natrium sehingga tidak dapat diserap dan dimanfaatkan oleh tubuh sehingga daya cernanya menurun. ${ }^{40}$

Protein juga dapat berikatan kuat dengan makromolekul lainnya seperti ikatan dengan polisakarida dan serat pangan sehingga menurunkan kecernaan protein. Serat pangan yang terkandung dalam tepung kedelai dapat mempengaruhi aktivitas enzimenzim protease. Apabila serat pangan berikatan dengan protein, enzim protease akan sulit untuk melakukan penetrasi untuk memutus ikatan peptidanya. Hal ini menyebabkan protein tersebut tidak dapat tercerna dengan baik sehingga nilai cerna proteinnya menurun dan absorpsi asam amino menjadi kurang efisien. ${ }^{41}$

\section{Organoleptik}

\section{Parameter Warna}

Adapun pada parameter warna, formula enteral P1 memiliki warna yang paling disukai dengan skor tertinggi sebesar 4,12 $\pm 0,72$ dengan kategori suka dibandingkan dua formula lainnya. Karakteristik formula enteral Hepatogomax yang dihasilkan berwarna putih agak kecoklatan seiring dengan bertambahnya perbandingan tepung kedelai. Hal ini menunjukkan perbandingan tepung kedelai yang lebih sedikit dapat meningkatkan penerimaan dalam hal warna formula enteral.

Panelis lebih menyukai warna formula enteral yang lebih putih (perbandingan tepung kedelai yang lebih sedikit). Warna putih pada formula enteral Hepatogomax berasal dari tepung susu kambing yang memiliki karakteristik warna lebih putih dari susu sapi karena susu kambing tidak mengandung karoten sebagaimana susu sapi yang menyebabkan warna agak kekuningan. $^{44}$ Warna kecoklatan berasal dari karakteristik tepung kedelai yang mengalami pencoklatan (browning) akibat proses pengeringan. Proses penyeduhan menggunakan air panas juga menyebabkan warna formula enteral menjadi kecoklatan karena terjadi reaksi Maillard yang merupakan reaksi antara gugus karbonil (gula pereduksi) dengan gugus amino (asam amino, peptida dan protein) apabila keduanya dipanaskan atau tersimpan dalam waktu yang relatif lama. Dalam produk susu, proses tersebut dimulai dari kondensasi laktosa dengan residu asam amino bebas lisin dalam protein susu (laktosilasi). ${ }^{45}$

\section{Parameter Aroma}

Hasil nilai organoleptik menunjukan bahwa formula P1 memiliki aroma yang paling disukai dengan

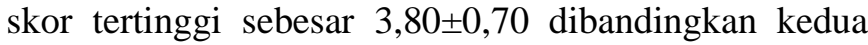
formula lainnya dimana formula P1 dengan perbandingan tepung kedelai lebih sedikit. Tepung susu kambing dalam jumlah yang lebih banyak dapat mengurangi aroma langu tepung kedelai sehingga aroma yang dihasilkan lebih disukai panelis.

Aroma langu dari kedelai dihasilkan oleh adanya oksidasi enzimatik asam linoleat dan asam linolenat oleh lipoxygenase genes (Lox) menghasilkan heksanol. ${ }^{32}$ Berbeda dengan kedelai yang memiliki aroma langu, susu kambing yang dipakai tidak menghasilkan aroma khas kambing (goaty) karena menggunakan susu bubuk dengan penambahan gula. Gugus gula akan bereaksi dengan amino protein susu yang disebut dengan reaksi glikasi (reaksi Maillard). Reaksi glikasi ini yang berperan dalam menghilangkan aroma khas tersebut pada susu kambing.$^{46}$ Aroma langu dapat diatasi dengan penambahan vanili. Menurut Peraturan Kepala Badan Pengawas Obat dan Makanan tahun 2016, batas maksimum penggunaan perisa vanili adalah $5 \mathrm{mg} / 100 \mathrm{ml}^{47}$

\section{Parameter Rasa}

Formula enteral P1 memiliki skor tertinggi pada rasa sebesar 3,80 $\pm 0,96$ (netral) dibandingkan dua formula lainnya. Hal ini menunjukkan perbandingan tepung susu kambing yang lebih banyak dapat meningkatkan penerimaan dalam hal rasa formula. Semakin banyaknya perbandingan tepung kedelai mengurangi tingkat kesukaan rasa dari formula enteral. Hal ini disebabkan tepung kedelai masih menghasilkan sedikit rasa pahit karena mengandung komponen volatil 2-propanol dalam biji kedelai. ${ }^{32}$ Tepung susu kambing yang digunakan merupakan susu bubuk dengan gula yang menambahkan rasa manis pada formula enteral sehingga perbandingan tepung susu kambing yang lebih banyak dapat mengurangi rasa pahit dari kedelai. Penambahan gula pasir pada formula enteral Hepatogomax juga meningkatkan rasa manis. Selain berkontribusi memberikan rasa manis, gula juga merupakan sumber karbohidrat sederhana karena mudah larut dalam air dan dapat langsung diserap oleh tubuh untuk diubah menjadi energi. ${ }^{48}$

\section{Parameter Tekstur}

Adapun parameter tekstur, formula enteral P1 memiliki tekstur yang paling disukai dengan skor tertinggi sebesar 3,96 $\pm 0,67$ (netral) dibandingkan dua formula lainnya. Hal ini menunjukkan bahwa tingkat kesukaan panelis terhadap tekstur berbanding terbalik dengan semakin banyaknya tepung kedelai yang ditambahkan. Tepung kedelai menghasilkan formula enteral dengan tekstur sedikit berpasir karena adanya kandungan serat dalam kedelai, dimana dalam 100 gram bahan kedelai memiliki serat 5,1 gram. $^{49}$ 


\section{Rekomendasi Formula Enteral Terpilih}

Formula enteral Hepatogomax yang telah mendekati persyaratan zat gizi penyakit hati menurut ESPEN adalah formula P1 dengan perbandingan tepung kedelai dan tepung susu kambing sebesar 45:55. Formula P1 dipilih karena nilai viskositas, kadar lemak, kandungan energi, densitas energi yang memenuhi syarat, serta daya cerna protein yang paling tinggi walaupun memiliki kadar protein terendah. Formula P1 dari segi organoleptik juga merupakan formula terpilih dengan skor tertinggi dari semua parameter dimana warna dalam kategori suka, sedangkan aroma, rasa dan tekstur dalam kategori netral skor tertinggi pada seluruh parameter.

\section{SIMPULAN}

Makin tinggi perbandingan tepung kedelai, makin tinggi viskositas formula dan kandungan protein. Sebaliknya, semakin tinggi perbandingan tepung susu kambing, maka semakin tinggi kandungan lemak, karbohidrat, dan densitas energi. Tidak ada pengaruh perbandingan kandungan formula terhadap daya cerna protein. Berdadarkan uji organoleptik, makin tinggi kandungan susu kambing, makin tinggi penerimaan pada semua aspek yaitu warna, aroma, rasa dan tekstur.

\section{SARAN}

Apabila formula enteral Hepatogomax diberikan secara oral, maka aroma langu dapat diatasi dengan menambahkan perisa vanili. Peningkatan daya cerna protein dapat dilakukan dengan cara menghilangkan kulit ari kedelai sebelum pembuatan tepung kedelai yang bertujuan untuk mengurangi kandungan serat kedelai. Selain itu perlu dilakukan pengujian asam amino terutama Branched-Chain Amino Acids (BCAA) untuk mengetahui kadar asam amino formula enteral yang dibuat.

\section{UCAPAN TERIMA KASIH}

Terima kasih kami ucapkan kepada di Laboratorium Terpadu Universitas Diponegoro, Laboratorium Analisa CV Chem-Mix Pratama Yogyakarta, dan subjek penelitian yang telah berpartisipasi dalam penelitian ini.

\section{DAFTAR PUSTAKA}

1. Kalaitzakis E. Gastrointestinal dysfunction in liver cirrhosis. World Journal Gastroenterology. 2014;20(40):14686-95.

2. Mokdad AA, Lopez AD, Shahraz S, Lozano R, Mokdad AH, Stanaway J, et al. Liver cirrhosis mortality in 187 countries between 1980 and 2010:
A systematic analysis. BMC Medicine. 2014;12(145):1-24.

3. EASL The Home of Hepatology. Fast facts about liver disease. In: The International Liver Congress. Barcelona; 2016.

4. Sinurat LR, Purba BT. Peningkatan status gizi pasien sirosis hepatis melalui regimen nutrisi di RS Sari Mutiara Medan. Idea Nursing Journal. 2018;9(2):1-3.

5. Cheung K, Lee SS, Raman M. Prevalence and mechanisms of malnutrition in patients with advanced liver disease, and nutrition management strategies. Clinical Gastroenterology Hepatology. 2012;10(2):117-25.

6. Maharshi S, Sharma BC, Srivastava S. Malnutrition in cirrhosis increases morbidity and mortality. Journal of Gastroenterology and Hepatology. 2015;30:1507-13.

7. Bemeur C, Desjardins P, Butterworth RF. Role of nutrition in the management of hepatic encephalopathy in end-stage liver failure. Journal of Nutrition Metabolism. 2010;1-12.

8. Purnak T, Yilmaz Y. Liver disease and malnutrition. Best Practice \& Research Clinical Gastroenterology. 2013;27:619-29.

9. Silva M, Gomes S, Peixoto A, Torres-Ramalho P, Cardoso H, Azevedo R, et al. Nutrition in chronic liver disease. GE Portuguese Journal of Gastroenterology. 2015;1-9.

10. Plauth M, Muller-Nothmann. A guide for patients with liver diseases including guidlines for nutrition. 8th ed. Freiburg: Falk Foundation; 2006. $1-70 \mathrm{p}$.

11. Hapsari HTP. Pengendalian mutu dalam proses pembuatan makanan enteral di rumah sakit dustira cimahi [Skripsi]. Bogor : Institut Pertanian Bogor; 2012.

12. Huda N. Formulasi makanan cair alternatif berbasis tepung ikan lele (Clarias gariepinus) sebagai sumber protein [Skripsi]. Bogor : Institut Pertanian Bogor; 2014.

13. Plauth M, Cabre E, Riggio O, Assis-Camilo M, Pirlich M, Kondrup J, et al. ESPEN guidelines on enteral nutrition: Liver disease. Clinical Nutrition. 2006;25:285-94.

14. Gokturk HS, Selcuk H. Importance of malnutrition in patients with cirrhosis. Turk J Gastroenterol. 2015;26:291-6.

15. Eghtesa S, Poustchi $\mathrm{H}$, Malekzadeh $\mathrm{R}$. Malnutrition in liver cirrhosis: The influence of protein and sodium. Middle East Journal of Digestive Disease. 2013;5(2):65-75.

16. Saputra D. Penentuan daya cerna protein in vitro ikan bawal (Colossoma macropomum) pada umur panen berbeda. ComTech. 2014;5(2):1127-33.

17. eBookPangan. Karakteristik kedelai sebagai bahan 
pangan fungsional [Internet]. Jakarta: eBookPangan; 2006. 1-28 p. Available from: eBookPangan.com

18. Astawan M, Hazmi K. Karakteristik fisikokimia tepung kecambah kedelai. Pangan. 2016;25(2):105-12.

19. Genateh G, Mebrat A, Wubie A, Kendie H. Review on goat milk composition and its nutritive value. Journal of Nutrition Health Sciences. 2016;3(4):1-10.

20. Haenlein GFW. Goat milk in human nutrition. Small Ruminant Research. 2004;51:155-63.

21. Yangilar F. As a potentially functional food: goats' milk and products. Journal of Food Nutrition Research. 2013;1(4):68-81.

22. Mwenze PM. Functional properties of goats' milk: A review. Research Journal Agriculture and Environmental Management. 2015;4(9):343-9.

23. Zenebe T, Ahmed N, Kabeta T, Kebede G. Review on medicinal and nutritional values of goat milk. Academic Journal of Nutrition. 2014;3(3):30-9.

24. Ayustaningwarno F. Teknologi pangan teori praktis dan aplikasi. 1st ed. Yogyakarta: Graha Ilmu; 2014. 1-8 p.

25. eBookPangan. Pengujian organoleptik (evaluasi sensori) dalam industri pangan [Internet]. Jakarta: eBookPangan; 2006. 1-41 p. Available from: eBookPangan.com

26. Agusman. Modul penanganan mutu fisis (organoleptik). Semarang: Program Studi Teknologi Pangan Universitas Muhammadiyah Semarang; 2013. 1-26 p.

27. Santoso EB. Pengaruh penambahan berbagai jenis dan konsentrasi susu terhadap sifat sensoris dan sifat fisikokimia puree labu kuning [Skripsi]. Surakarta : Universitas Sebelas Maret; 2013.

28. Bourne M, Santoso EB. Food texture and viscosity: concept and measurement. Second Edition. 2013. 78-81 p.

29. Lumbantoruan P, Yulianti E. Pengaruh suhu terhadap viskositas minyak pelumas. Sainmatika. 2016;13(2):26-34.

30. American Dietetic Association. National Dysphagia Diet Task Force, American Dietetic Association. Viscosity level for oral and enteral feedings. In: National dysphagia diet:Standardization for optimal care. Chicago: American Dietetic Association; 2002.

31. Lindriati T, Praptiningsih Y, Wijayanti DF. Karakteristik fisis gel edible film yang dibuat dengan variasi $\mathrm{pH}$ dan rasio kasein dan tapioka. Jurnal Imu Dasar. 2014;15(1):51-8.

32. Ravi R, Taheri A, Khandekar D, Millas R. Rapid profiling of soybean aromatic compounds using electronic nose. Biosensors. 2019.9(66):1-13.

33. Hamad A, Ma'ruf A. Produksi lecithin dari vegetable oils menggunakan proses acid degumming. In: Prosiding Senatek 2015 Fakultas Teknik, Universitas Muhammadiyah Purwokerto. Purwokerto: Universitas Muhammadiyah Purwokerto; 2015. p. 111-5.

34. Apri N. Profil medium chain fatty acids (MCFA) minyak kelapa (Virgin Coconut Oil/VCO, minyak simplah, pliek U, klentik, dan kopra) dibandingkan dengan minyak sawit. Sagu. 2013;12(2):23-31.

35. Shah ND, Limketkai BN. Nutrition issues in gastroenterology, series \#160 : The use of mediumchain triglycerides in gastrointestinal disorders. In Parrish CR (ed). Practical gastroenterology. 2017:20-26.

36. Siregar NS. Karbohidrat. Jurnal Ilmu Keolahragaan. 2014;13(2):38-44.

37. Plauth M, Bernal W, Dasarathy S, Merli M, Plank LD, Schutz T, et al. ESPEN guideline on clinical nutrition in liver disease. Clinical Nutrition. 2019. https://doi.org/10.1016/j.clnu.2018.12.022

38. Muchtadi D. Nutrifikasi Protein. In: Nutrifikasi Pangan. 1st ed. Tangerang Selatan: Universitas Terbuka; 2008. p. 1.1-1.4.

39. Duodu KG, Taylor JR., Belton PS, Hamaker BR. Factors affecting sorghum protein digestibility. Journal of Cereal Science. 2003;38:117-31.

40. Gilani GS, Xiao CW, Cockell KA. Impact of antinutritional factors in food proteins on the digestibility of protein and the bioavailability of amino acids and on protein quality. British Journal of Nutriion. 2012;108:S315-S332.

41. Kanaka DA, Ayustaningwarno F. Nilai cerna protein in-vitro biskuit dengan substitusi kecambah kedelai (Glycine $\max (L$.) Merril) dan pisang (Musa paradisiaca sp.) sebagai makanan sehat untuk anak sekolah dasar. Journal of Nutrition College. 2015;4(2):141-6.

42. Budiman. Kandungan nutrisi dan daya cerna protein secara in vitro snack ekstruksi berbahan grits jagung yang disubstitusi dengan tepung putih telur sebagai sumber protein [Skripsi]. Bogor : Institut Pertanian Bogor; 2008.

43. Boyce J, Wijesinha-Bettoni R, Burlingame B. Protein quality evaluation twenty years after the introduction of the protein digestibility corrected amino acid score method. British Journal of Nutrition. 2012;108:S183-S211.

44. Ullah R, Khan S, All H, Bilal M, Saleem M. Identification of cow and buffalo milk based on beta carotene and vitamin-A concentration using fluorescence spectroscopy. Plos one. 2017;12(5):110.

45. Tehrany EA, Sonneveld K. Packaging and the shelf life of milk powders. In: Robertson GL, editor. Food packaging and shelf life: A pratical guide. 1st Editio. Boca Raton: CRC Press; 2009. p. 
$127-37$.

46. Anggraeni RH, Legowo AM, Al-Baarri AN. Intensitas warna dan aroma pada susu skim kambing akibat proses glikasi dengan penambahan gula D-Fruktosa, L-Fruktosa, dan D-Tagatosa. Jurnal Aplikasi Teknologi Pangan. 2013;2(3):1569.

47. BPOM. Peraturan kepala badan pengawas obat dan makanan nomor 22 tahun 2016 tentang persyaratan penggunaan bahan tambahan pangan perisa. Jakarta; 2016.

48. Darwin P. Menikmati gula tanpa rasa takut. Yogyakarta: Sinar Ilmu; 2014.

49. Gupta R. Nutrient analysis of raw and processed soybean and development of value added soybean noodles. Inventi Rapid : Life Style. 2014;1:1-6 